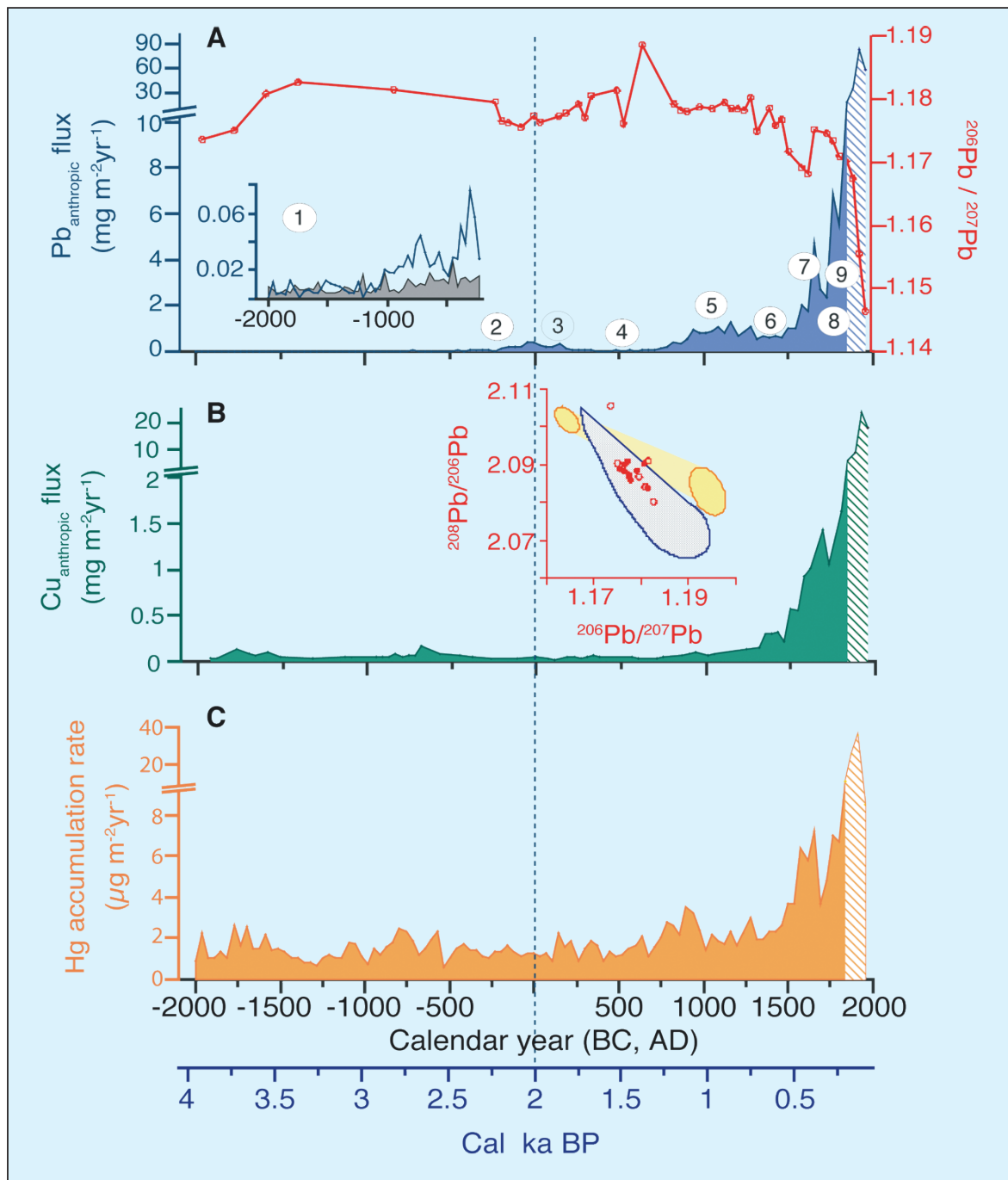

Figure 2: Lead (Pb), copper (Cu) and mercury ( $\mathrm{Hg}$ ) chronologies in Lindow Bog (UK). A) Fluxes of anthropogenic $\mathrm{Pb}$ and ${ }^{206} \mathrm{~Pb} / 207 \mathrm{~Pb}$ from $2000 \mathrm{BC}$ to $1800 \mathrm{AD}$ with focus on the pre-Roman period (Inset) to emphasize the early increase in Pb deposition at 1000 BC (from Le Roux et al., 2004). The natural estimated Pb flux is also represented (light gray). 1) Begin of use of leaded bronze in Great Britain, 2) Iron Age, 3) Roman Occupation (43 AD-410 AD), 4) Dark Ages, 5) Norman-Medieval Period, 6) Hundred Years War, plague epidemic (1349 AD), 7) German workers brought to re-organize the mines (16 th century), 8) plague epidemic (1645 AD), 9) Industrial Revolution. B) Flux of copper (green, unpublished data) and Pb three-isotope plot (inset) with peat samples (red), UKores (blue) and Spanish ores (yellow), indicating UKores as the likely source of Pb atmospheric deposition over Iron Age and Roman Occupation. C) Hg accumulation rate (unpublished data). Hatched section: recent period possibly disturbed by peat farming. spheric dust deposition may have varied considerably with climate change during the Holocene (e.g., Kylander et al., 2005; Shotyk et al., 2001). There is also a clear need for interdisciplinary studies linking paleoenvironments, geochemistry and archeology (i.e., archival records), as well as atmospheric chemistry and transport modeling. There is tremendous opportunity to employ new analytical tools for the characterization of pollutant aerosols (e.g., Scanning electron microscope, Laser Ablation inductively coupled plasma mass spectrometry) as well as to investigate other elements that have been less studied (e.g., Rare Earth Elements, Platinum Group Elements) but may provide new insights into both nutrient input by natural atmospheric dusts during pre-anthropogenic times, and human impacts on the environment.

\section{References}

Nriagu, J.0., 1983: Lead and lead poisoning in the Antiquity, John Wiley, New York.

Shotyk, W., Weiss, D., Appleby, P.G., Cheburkin, A.K., Frei, R., Gloor, M., Kramers, J.D., Reese, S. and van der Knaap, W.O., 1998: History of atmospheric lead deposition since $12,370^{14} \mathrm{C}$ yr BP recorded in a peat bog profile, Jura Mountains, Switzerland, Science, 281 $1635-1640$

Shotyk, W. and Le Roux, G., 2005: Biogeochemistry and Cycling of Lead. In: Sigel, A., et al. (Eds), Biogeochemical Cycles of the Elements. Metal lons in Biological Systems, M. Dekker, New York 43: 240275.

De Vleeschouwer, F, Fagel, N., Cheburkin, A, Pazdur, A., Sikorski, J, Mattielli, N., Renson, V., Fialkiewicz, B. and Piotrowska, N., 2009: Anthropogenic impacts in North Poland over the last 1300 years, The Science of the Total Environment, 407: 5674-5684.

Le Roux, G., Weiss, D., Grattan, J., Givelet, N., Krachler, M., Cheburkin, A., Rausch, N., Kober, B. and Shotyk, W., 2004: Identifying the sources and timing of ancient and medieval atmospheric lead pollution in England using a peat profile from Lindow bog, Manchester, Journal of Environmental Monitoring, 6: 502-510.

\title{
The northern peatland carbon pool and the Holocene
}

\section{carbon cycle}

David W. Beilman', G.M. MacDonald² and Z. Yu ${ }^{3}$

'Department of Geography, University of Hawai`i Mānoa, USA; beilman@hawaii.edu

Institute of the Environment, University of California, Los Angeles, USA; ${ }^{3}$ Department of Earth and Environmental Sciences, Lehigh University, Bethlehem, USA

\section{Understanding the role of peatlands in the Holocene carbon cycle will help predict the response of northern carbon stores to a changing climate.}

Northern peatlands hold a large proportion of Northern Hemisphere land carbon (equivalent to as much as $1 / 3$ of total global soil carbon) and are significant and active players in the global carbon cycle. An improved understanding of the controls and future dynamics of these carbon-rich ecosystems is possible from study of their Holocene history and previous carbon response to climate change. Peatland information relevant to Earth system dynamics includes the spatiotemporal pattern of expansion to the current $\sim 4 \times 10^{6} \mathrm{~km}^{2}$ occupied by northern peatlands, the variations in carbon accumulation at millennial and multi-centennial timescales, and the distribution of today's 270-450 Pg (1 Pg = 1 gigatonne $=10^{15} \mathrm{~g}$ ) of peatland carbon as it relates to current climate.

\section{Peatland expansion}

Recently published datasets of basal ${ }^{14} \mathrm{C}$ (radiocarbon) dates from extant peatlands indicate that northern peatlands have been sequestering atmospheric $\mathrm{CO}_{2}$ and cycling land carbon at least since the early Holocene (Figs. 1 and 2; MacDonald et al., 2006; Gorham et al., 2007; Yu et al., 2009; Korhola et al., 2010). By 8 cal ka BP, peatlands had developed extensively across the continents in the Northern Hemisphere (Fig. 2e). This rapid wetland expansion contributed to the early Holocene rise and sustained peak in $\mathrm{CH}_{4}$ concentrations after the Younger Dryas until about $8 \mathrm{cal}$ ka BP (Fig. 2c; MacDonald et al., 2006), and 
a subsequent expansion at 4 cal ka BP possibly contributed to the late Holocene $\mathrm{CH}_{4}$ rise (Korhola et al., 2010). The carbon that accumulated on land as these early Holocene peatlands expanded could also have influenced the $\sim 7$ ppmv decrease in $\mathrm{CO}_{2}$ at 11 - 8 cal ka BP (Fig. 2b) if this new carbon pool was large. A range of conservative estimates suggests that 29-98 Pg carbon existed as northern peat carbon by $8 \mathrm{cal} \mathrm{ka}$ BP (MacDonald et al., 2006; Yu et al., 2009) and this pool could have been substantially larger. These spatially referenced datasets of peat basal ages are large (Fig. 1) and continue to grow, providing additional opportunities for creative data-mining to address important Holocene carbon cycle questions.

\section{Carbon accumulation}

Numerous studies also report rates of Holocene carbon accumulation in northern peatlands. A characteristic feature of these data is a highly variable carbon accumulation history both within sites and between regions, indicating the complex balance between past plant growth and total Holocene losses via decomposition. However, a recent synthesis of available data from 33 Northern Hemisphere sites (Fig. 1) reveals high carbon accumulation during the early Holocene at many locations (Fig. $2 \mathrm{~d}$ ). For example, the greatest carbon accumulation appears to have occurred between 11 and 9 cal ka BP in Alaska, and between 10 and $8 \mathrm{cal}$ ka BP at some sites in West Siberia (see Yu et al., 2009). Differences in the timing of peak carbon accumulation between regions were affected by delayed deglaciation, different timing of Holocene Thermal Maximum conditions, changes in the seasonality of insolation (Fig. 2a), and other landscape and atmospheric circulation factors. The available data suggest that an overall slowdown of carbon accumulation may have occurred after about 4 cal ka BP at many sites (Fig. 2d; Yu et al., 2009), which may be related to neoglacial cooling and permafrost formation in continental regions. Evidence for a renewed lateral expansion of peatlands in the mid-Holocene (Korhola et al., 2010) is seemingly at odds with evidence for a slowdown in vertical carbon accumulation after 4 cal ka BP (Fig. 2). Such a discrepancy suggests that the role of the large peat carbon pool in late Holocene $\mathrm{CO}_{2}$ and $\mathrm{CH}_{4}$ changes should be re-evaluated. Existing data are currently limited, but the wide distribution of peatlands across the Northern Hemisphere provides the possibility for much more information and a better understanding of ecosystem

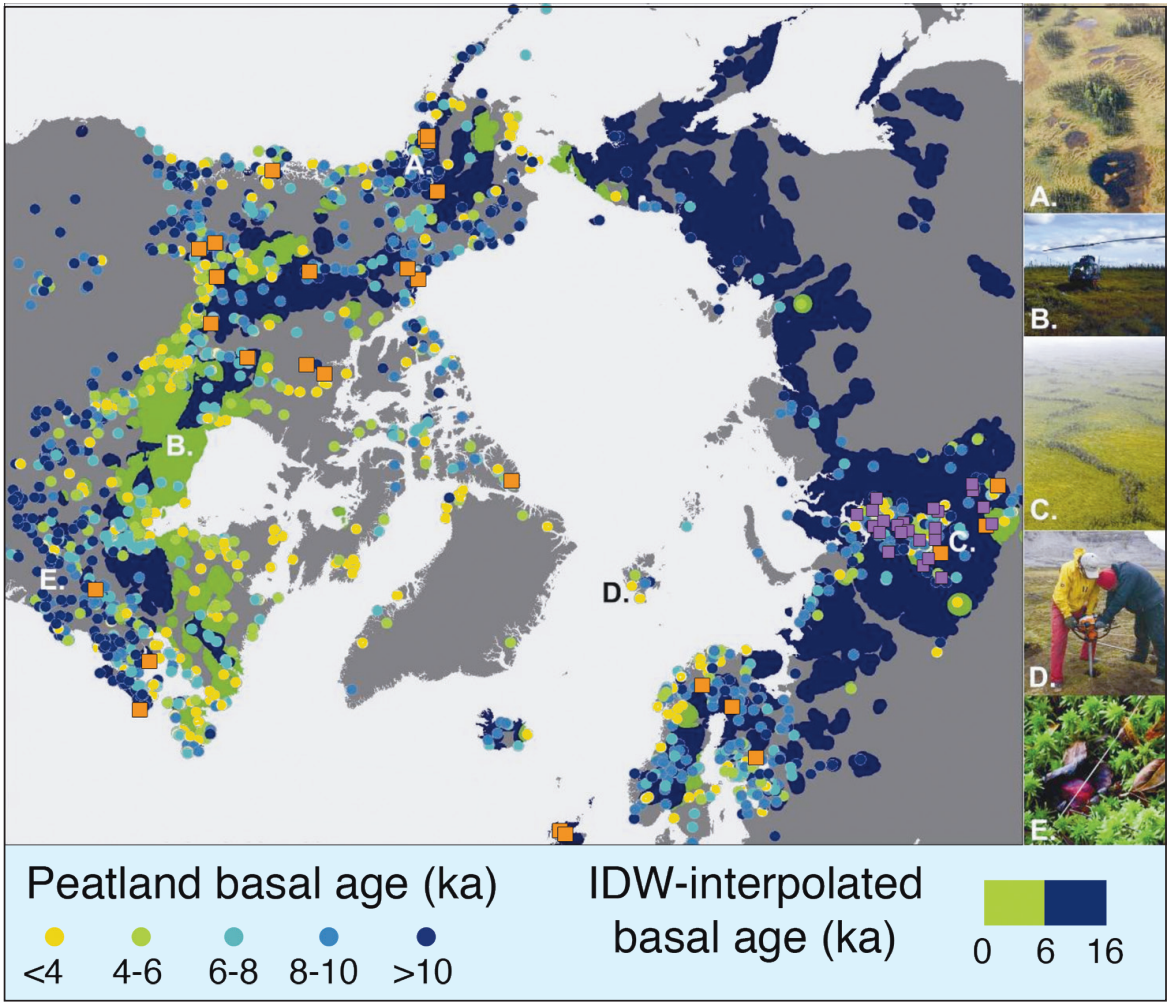

Figure 1: Spatial pattern of the age of peatland establishment across the northern high latitudes showing basal radiocarbon ages (circles; $n=2380$ IntCal04-calibrated ages; MacDonald et al., 2006; Gorham et al., 2007), IDWinterpolated (inverse distance weighted) surface of basal ages and the generalized pattern of establishment within $50 \mathrm{~km}$ of the distribution of boreal/taiga peatlands (colored shading), the location of carbon accumulation sites in Figure $2 d$ (orange squares), and in Figure $3 a$ (West Siberia, purple squares). Figure modified from Yu et al., 2009. Letters correspond to the location of photos to the right of the map.

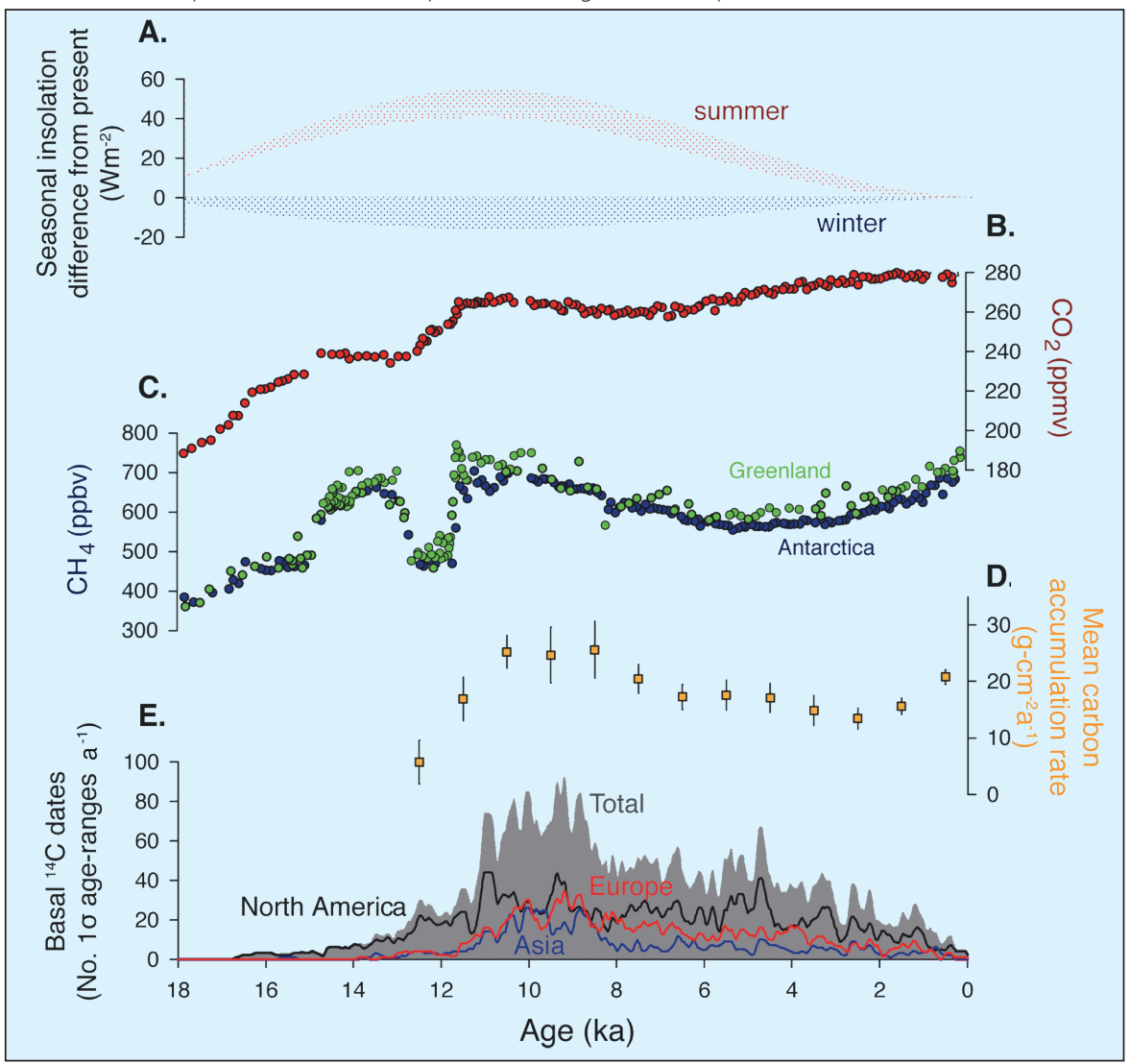

Figure 2: Holocene timing of peatland establishment and carbon accumulation compared to variations in northern insolation and atmospheric $\mathrm{CH}_{4}$ and $\mathrm{CO}_{2}$. $\boldsymbol{A}$ ) Winter (Dec) vs summer (June) insolation difference from the present (Berger and Loutre 1991; stippled bands indicate insolation between 40 and $80^{\circ} \mathrm{N}$ ). B) Atmospheric $\mathrm{CO}_{2}$ recorded in EPICA Dome C Antarctic ice core (red circles; Monnin et al., 2001; Flückiger et al., 2002). C) Atmospheric CH recorded in Greenland (green circles; GISP2; Brooket al., 2000) and Antarctica (blue circles; EPICA Dome C; Monnin et al., 2001; Flückiger et al., 2002). D) Composite curve of time-weighted mean ( \pm SE) carbon accumulation at 33 sites in 1 ka bins (Yu et al., 2009). E) Occurrence frequency of the radiocarbon age of basal peat deposits (1-sigma age ranges) on each of the northern continents (MacDonald et al., 2006). The rapid early Holocene expansion of northern peatlands between about 11 and 8 cal $\mathrm{ka} B P$ is coincident with high carbon accumulation rates at many sites. This period of rapid peatland expansion and accumulation during the summer insolation maximum may have contributed significantly to the early Holocene rise in $\mathrm{CH}_{4}$ and the slowdown and decrease in $\mathrm{CO}_{2}$. Figure modified from MacDonald et al., 2006 and Yu et al., 2009. 

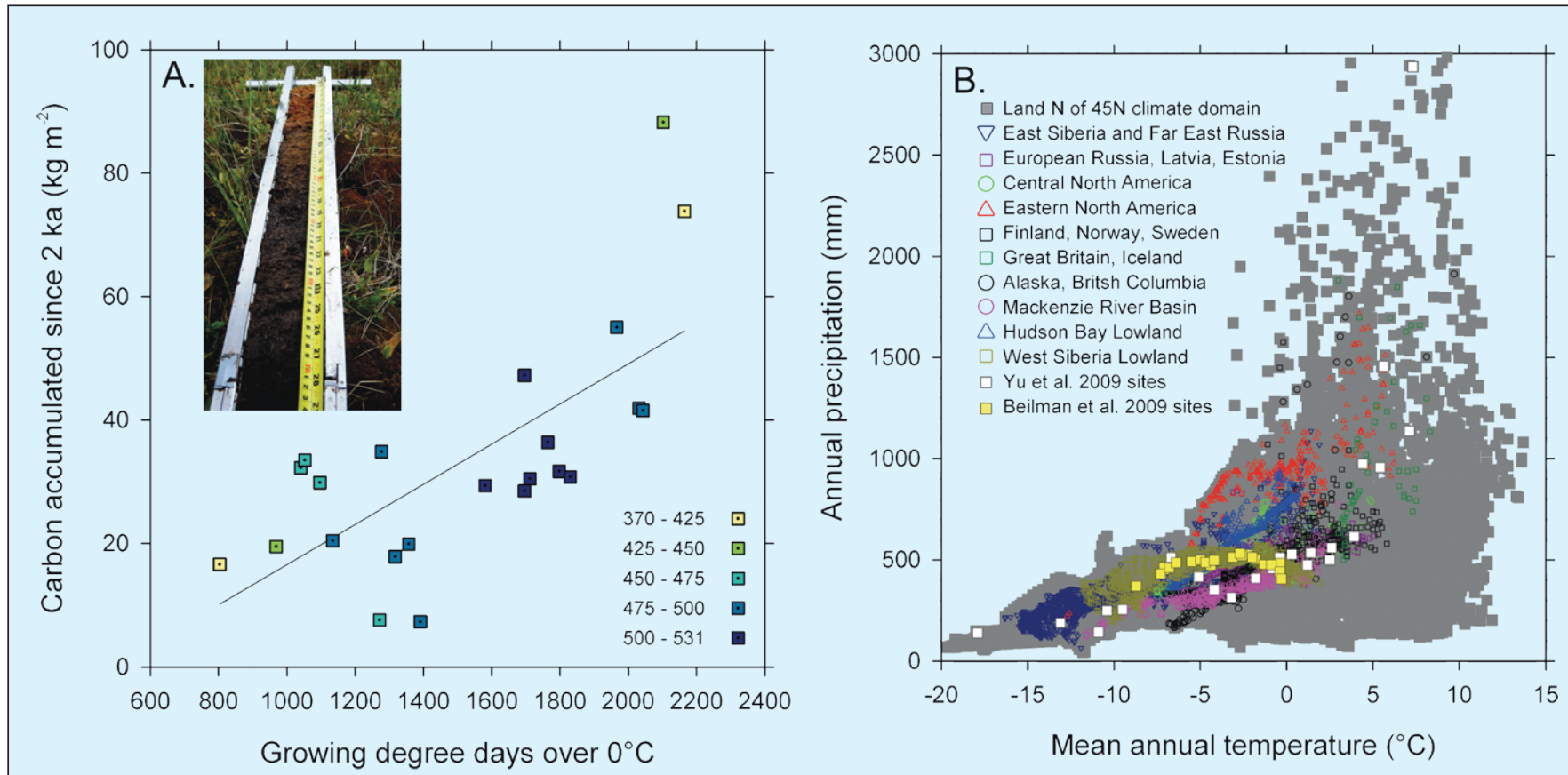

Figure 3: Carbon accumulation since 2 ka in West Siberia and the modern climate space of northern peatland distribution. A) Relationship between modern growing-season temperature and the mass of peat carbon younger than 2 cal ka BP at 23 sites in West Siberia (modified from Beilman et al., 2009). Colors show annual precipitation (mm) at each site as in Figure 3b. Inset photo shows a core (still in box corer) of the first $70 \mathrm{~cm}$ of a $400 \mathrm{~cm}$ deposit; the depth of peat accumulated over the last $2 \mathrm{ka}$ in West Siberia ranges from 11 to $272 \mathrm{~cm}$. B) The distribution in climate space of 0.5 by $0.5^{\circ}$ land grids north of $45^{\circ} \mathrm{N}$ (gray) and grids within northern peatland regions (colored symbols) shown by the colored shading in Figure 1 (modified from Yu et al. 2009). Climate data are gridded 1960-1990 mean annual temperature and annual precipitation.

and land carbon response to Holocene climate change.

The last 2 ka offers an opportunity to investigate the dynamics of terrestrial carbon pools and processes under conditions more similar to the present. By 2 ka ago, northern peatlands had expanded into much of their present extent (Fig. 1), and northern growing-season insolation had decreased to levels similar to today (Fig. 2a). Data from 23 sites across West Siberia show a large range of total carbon accumulated over the last $2 \mathrm{ka}$ ( 7 to $88 \mathrm{~kg} \mathrm{~m}^{-2}$ ), and a pattern between sites that deviates from the pattern of total Holocene carbon accumulation (Beilman et al., 2009). This mismatch suggests that peatlands that were substantial carbon sinks during the early and mid-Holocene have not necessarily been the location of greatest carbon accumulation in the recent past. On the other hand, a strong north-south trend is evident that is positively correlated with mean annual temperature (Beilman et al., 2009) and growing season warmth (Fig. 3a). Developing reconstructions of carbon accumulation rate changes over the recent past could help tease apart the influence of temperature, a direct control on both plant growth and soil respiration, and the influence of hydrological change. Such high-quality data for multi-centennial variations in carbon dynamics are still scant, but would provide insight into the response of land carbon to the relatively well-studied climates of the Medieval Climate Anomaly and the Little Ice Age.
These data and analyses would provide a useful constraint on understanding the relationship between climate and $\mathrm{CO}_{2}$ (see Cox and Jones, 2008).

\section{Peatland carbon and modern climate}

Knowing the current climate domain of today's northern carbon pools is relevant to predicting their fate in the face of global change. Northern peatland carbon typically occurs where annual mean temperatures are between $-12^{\circ}$ and $5^{\circ} \mathrm{C}$ and annual precipitation is between 200 and $1000 \mathrm{~mm}$ (Fig. 3b). However, many important regional differences are evident. Considering carbon-rich regions, the peatlands of West Siberia and the Mackenzie River Basin experience mean annual temperatures $7^{\circ} \mathrm{C}$ colder than those in the Hudson Bay Lowland. The warmest peatlands in these three regions (between -2 and $2^{\circ} \mathrm{C}$ ) receive very different precipitation inputs, with southern West Siberia and southern Mackenzie peatlands receiving half as much annual precipitation as their warm counterparts in the southern Hudson Bay region (Fig 3b; Yu et al., 2009). In this way, regional differences in the response of northern carbon were likely important in the Holocene carbon cycle, and will likely be important in future carbon dynamics. The further application of this kind of climate envelope analysis, and its potential combination with process modeling, provides another opportunity to better understand the possible trajec- tories in different regions of this very large terrestrial carbon pool.

\section{References}

Beilman, D.W., MacDonald, G.M., Smith, L.C. and Reimer P.J., 2009: Carbon accumulation in peatlands of West Siberia over the last 2000 years, Global Biogeochemical Cycles, 23: GB1012, doi:10.1029/2007GB003112.

Cox, P. and Jones C., 2008: Illuminating the modern dance of climate and $\mathrm{CO}_{2}$, Science, 321: 1642-1644, doi:10.1126/science. 1158907.

Korhola, A. Ruppel, M. Seppa, H. Valiranta, M., Virtanen, T. and Weckstrom, J., 2010: The importance of northern peatland expansion to the late-Holocene rise of atmospheric methane, Quaternary Science Reviews, 29: 611-617, doi:10.1016/j.quascirev.2009.12.010.

MacDonald, G.M., Beilman, D.W., Kremenetski, K.V., Sheng, Y., Smith L.C. and Velichko, A.A., 2006: Rapid development of the circumarctic peatland complex and atmospheric $\mathrm{CH}_{4}$ and $\mathrm{CO}$ variations, Science, 314: 285-288, doi:10.1126/science.1131722.

Yu, Z.C., Beilman, D.W. and Jones, M.C., 2009: Sensitivity of Northern Peatland Carbon Dynamics to Holocene Climate Change. In: Baird, A., et al., (Eds), Carbon Cycling in Northern Peatlands, AGU Geophysical Monograph, American Geophysical Union, 184: 5569. doi:10.1029/2008GM000822. A PDF reprint is available by contacting the authors.

For full references please consult:

http://www.pages-igbp.org/products/newsletters/ref2010_1.html 


\section{D.W. Beilman, G.M. MacDonald and Z. Yu}

Beilman, D.W., MacDonald, G.M., Smith, L.C. and Reimer P.J., 2009: Carbon accumulation in peatlands of West Siberia over the last 2000 years, Global Biogeochemical Cycles, 23: GB1012, doi:10.1029/2007GB003112.

Berger, A. and Loutre M.F. 1991: Insolation values for the climate of the last 10 million years, Quaternary Science Reviews, 10: 297-317, doi:10.1016/0277-3791(91)90033-Q.

Brook, E.J., Harder, S., Severinghaus J., Steig E.J. and Sucher, C.M., 2000: On the origin and timing of rapid changes in atmospheric methane during the last glacial period, Global Biogeochemical Cycles, 14: 559-572.

Cox, P. and Jones C., 2008: Illuminating the modern dance of climate and $\mathrm{CO}_{2}$, Science, $\mathbf{3 2 1}$ : 1642-1644, doi:10.1126/science.1158907.

Flückiger, J., Monnin, E., Stauffer, B., Schwander, J., Stocker, T.F., Chappellaz, J., Raynaud, D. and Barnola, J-M., 2002: High-resolution Holocene $\mathrm{N}_{2} \mathrm{O}$ ice core record and its relationship with $\mathrm{CH}_{4}$ and $\mathrm{CO}_{2}$, Global Biogeochemical Cycles, 16: GB1010, doi:10.29/2001GB001417.

Gorham, E., Lehman, C., Dyke, A., Janssens, J. and Dyke, L., 2007: Temporal and spatial aspects of peatland initiation following deglaciation in North America, Quaternary Science Reviews, 26: 300-311, doi:10.1016/j.quatscirev.2006.08.008.

Korhola, A., Ruppel, M. Seppa, H. Valiranta, M., Virtanen, T. and Weckstrom J. 2010: The importance of northern peatland expansion to the late-Holocene rise of atmospheric methane, Quaternary Science Reviews, 29: 611-617, doi:10.1016/j.quascirev.2009.12.010.

MacDonald, G.M., Beilman, D.W., Kremenetski, K.V., Sheng, Y., Smith, L.C. and Velichko, A.A., 2006: Rapid development of the circumarctic peatland complex and atmospheric CH4 and CO2 variations, Science, 314: 285-288, doi:10.1126/science.1131722.

Monnin, E., Indermühle, A., Dällenbach, A., Flückiger, J., Stauffer, B., Stocker, T.F., Raynaud, D. and Barnola, J-M., 2001: Atmospheric CO2 concentrations over the last glacial termination, Science, 291: 112-114.

Yu, Z.C., Beilman, D.W. and Jones, M.C., 2009: Sensitivity of Northern Peatland Carbon Dynamics to Holocene Climate Change. In: Baird, A., et al., (Eds), Carbon Cycling in Northern Peatlands, AGU Geophysical Monograph, American Geophysical Union, 184: 55-69. doi:10.1029/2008GM000822. A PDF reprint is available by contacting the authors. 